\title{
Going digital multinationals: Navigating economic and social imperatives in a post- pandemic world
}

\author{
Niraja Srinivasan ${ }^{1}$ and \\ Lorraine Eden ${ }^{2}$ \\ ${ }^{1}$ Partner, NERA Economic Consulting, 1255 23rd
Street NW, Suite 600, Washington, DC 20037,
USA; ${ }^{2}$ Professor Emerita of Management and
Research Professor of Law, Texas A\&M University,
College Station, TX 77843-4221, USA \\ Correspondence: \\ L Eden, Professor Emerita of Management \\ and Research Professor of Law, Texas A\&M \\ University, College Station, TX 77843-4221, \\ USA \\ e-mail: leden@tamu.edu
}

\begin{abstract}
The COVID-19 pandemic has intensified the economic imperative facing brickand-mortar MNEs; i.e., their need to build commercial resilience in response to Industry 4.0 (4IR). The pandemic has also undone progress on the Sustainable Development Goals (SDGs), widened income inequalities, and created a new backlash against digital globalization such that the UN social imperative - the pledge to leave no one behind by achieving the SDGs by 2030 - now appears an impossible task. Could the "going digital" MNEs that are making substantial investments in 4IR technologies take a socially proactive stance and thereby provide a window of opportunity that would rebuild momentum on the UN social imperative? Our paper explores the possible social impacts of MNE digitalization initiatives, both directly through their corporate social responsibility (CSR) activities and indirectly through their global value and supply chains. Because digitalization can be used for the good but requires adequate harnessing, we argue that three changes are needed to ensure that the going digitals, with the assistance of UN agencies, can simultaneously address their economic imperative and facilitate progress on the UN's social imperative: (i) revamping the CSR function; (ii) making SDGs "matter"; and (iii) building a new UN-MNE coalition.

Journal of International Business Policy (2021) 4, 228-243.

https://doi.org/10.1057/s422 |4-021-00 I08-7
\end{abstract}

Keywords: Industry 4.0; global value chains; global supply chains; born digitals; going digitals; pandemic; corporate social responsibility; sustainable development; SDGs; Janus face

\section{INTRODUCTION}

In the 1970s and 1980s, Japanese automotive multinational enterprises (MNEs) were agents of change, leading a technological revolution in manufacturing from mass production to lean production (Roos, Jones \& Womack, 1990). In the 1990s, the Internet and the ICT (information and communication technologies) industry created the infrastructure for another round of technological change, now known as Industry 4.0 or 4IR (Schwab, 2016). 4IR was triggered by the digitization of data, the evolution of digital ICT infrastructures, and the growth of digital processing and storage (Øverby \& Audestad, 2018). Scholars, think tanks, and policymakers are now analyzing 4IR and its likely impacts on
Received: 11 January 2021

Revised: 15 March 2021

Accepted: 17 March 2021

Online publication date: 23 April 2021 
international trade, foreign direct investment (FDI), and global value chains (GVCs). ${ }^{1}$ Some scholars are also drawing lessons from earlier technological revolutions (Eden, 2019; Vickers \& Ziebarth, 2019) and prior economic crises (Cattaneo, Gereffi, \& Staritz, 2010).

Leading this round of technological change are pure or "born" digitals (Eden, 2018; Monaghan, Tippmann \& Coviello, 2020) and ICT firms (Bolwijn, Casella, \& Zhan, 2019; Casella \& Formenti, 2018; UNCTAD, 2017). ICT firms provide the infrastructure on which 4IR is built (Øverby \& Audestad, 2018). The born digitals use this ICT infrastructure, together with technologies such as "robotics-enabled automation and AI-enhanced systems, supply chain digitalization including platforms, cloud, Internet of Things (IoT), blockchain, and additive manufacturing and mass customization" (Zhan, 2021).

Born digitals offer automation, flexibility, and scalability, based on firm-specific advantages in intangibles and digital assets (Banalieva \& Dhanaraj, 2019; Monaghan et al., 2020). Compared to traditional brick-and-mortar MNEs, the GVCs of digital MNEs are much more "asset light" with fewer affiliates in developing countries (Casella \& Formenti, 2018: 114). In 4IR, born digitals are the new agents of change, pushing traditional firms in manufacturing and services into adopting digital technologies, much as the Japanese auto transplants in North America were agents of change fostering the adoption of lean production in the 1980s (Eden \& Molot, 1996). Born digitals are expected to complement, displace, or force the digital adaptation of traditional brick-and-mortar MNEs (Bolwijn, Casella, \& Zhan, 2019; Eden, 2019).

As a result, traditional MNEs are being forced to compete in 4IR by "going digital." Their adoption of 4IR technologies will likely "flatten, squeeze, or bend the 'smile curve' of GVCs" (Zhan, 2021). Looking ahead to the next 10 years, Zhan predicts that the GVCs of traditional MNEs will become more regional than global, with value creation more concentrated and manufacturing less fragmented. GVC diversification will be driven by resilience and national security concerns, with a shift towards mass customization, a reduction in international trade in intermediate goods, and an increase in services. Zhan also predicts growing FDI in infrastructure, public services, and "green" and "blue" economies.

The economic imperative driving brick-and-mortar firms to digitalize in response to 4IR has now been exacerbated by the 2020-2021 COVID-19 global pandemic (McKinsey, 2020b). The pandemic is fundamentally altering their rate of change, encouraging even faster digitalization. A July 2020 survey by McKinsey (2020a: 2) notes that "digital adoption has taken a quantum leap at both the organizational and delivery levels" during the pandemic. Katz (2020: 35) reinforces this point:

There's a popular meme that neatly captures the tipping point of digital: it is a short questionnaire asking who is driving your digital transformation. The first two options are "CEO" and "chief digital officer." Below that, highlighted with a bright red circle, is "COVID-19."

UNCTAD (2020b: 156) expects the combination of 4IR and the pandemic to fundamentally alter the long-term trajectory of "going global" that has been in place since the 1980s. The report sees a retreat from global production over the next 10 years as highly likely and argues the retreat will follow one of three possible trajectories: reshoring, regionalization, or replication. This view is shared by East and Kaspar (2020) and Enderwick and Buckley (2020). Zhan (2021) goes even further, predicting a fundamental shift in the investment-development paradigm. He argues the paradigm shift will be driven by four changes: an economic-governance realignment; the prevalence of 4IR worldwide; sustainability and corporate accountability matching other financial and technology investments; and a new resilience-oriented restructuring that becomes a permanent outcome of the pandemic.

While MNEs have been adapting to the twin economic imperatives of 4IR and the pandemic, governments have also been faced with their own difficult choices. The 2030 deadline set by the United Nations (2016) for achievement of the UN Sustainable Development Goals (SDGs) is a mere 9 years away. In January 2020, an editorial in Nature (2020) concluded that the SDGs were off track and faced a bleak future. The financing crisis faced by the SDGs was stressed by UNCTAD (2020a: 23) in its blunt assessment that the 2030 Agenda required "the largest investment push in history" and would necessitate major financial commitments not only from governments but also from 
MNEs. UNCTAD's assessment of the funding shortfall was an annual USD 2.5 trillion (UNCTAD, 2014).

The pandemic has also had a disproportionate impact on the world's most vulnerable peoples, with a striking disparity seen in the massive fiscal and economic stimulus and humanitarian response in developed countries versus the woefully inadequate support to businesses and people in developing countries (Chowdhury \& Sundaram, 2021). The pandemic "could undo the progress made in the last 6 years in SDG investment" (Zhan and SantosPaulino, 2021: 167). The UN social imperative has therefore become stronger and more urgent since the onset of the pandemic and now requires an immediate mobilization of funds into the SDGs. Not only has SDG investment fallen, but the widening inequalities caused by 4IR and the pandemic have led to a new backlash against globalization and to rising protectionism (Kobrin, 2017; Verbeke \& Hutzschenreuter, 2020). The UN social imperative, the pledge to leave no one behind by 2030, now looks an impossible task.

Perhaps, however, the social imperative may not be such an impossible task. Zhan and Santos-Paulino (2021) discuss a wide variety of policy measures that could accelerate investment, especially private sector investment, in the SDGs. Zhan (2021) predicts that 4IR would create a need for massive realignments of GVCs with possible investments in green and blue economies. Van Zanten and van Tulder (2020: 457) argue that the SDGs provide "an annual US\$12 trillion investment opportunity" for business. Could there be a window of opportunity where MNEs, in responding to their own economic imperatives, might also be induced to address the social imperative of the SDGs?

We argue that the economic imperative that MNEs face in terms of recovering from COVID-19 and thriving in 4IR can be compatible with the UN's social imperative of achieving meaningful progress on the SDGs. The window of opportunity arises, we believe, not so much from the born digital MNEs but rather from traditional brick-and-mortar MNEs that are digitalizing. Because these "going digital" MNEs must make substantial investments in 4IR technologies, a window of opportunity presents itself for movement on both the economic and social imperatives. Three developments are key for this opportunity to be realized: (i) revamping the corporate social responsibility (CSR) function within MNEs, (ii) making the SDGs "matter" for MNEs, and (iii) building a new UNMNE coalition. These changes would be made primarily by MNEs with the assistance of UN agency coalition forces.

\section{THE WINDOW OF OPPORTUNITY}

Most of the attention in 4IR has been paid to the born digital MNEs as the bellwethers of change. However, the largest investments, both domestic and international, in 4IR will be made by going digital MNEs as they respond to the twin imperatives of 4IR and the pandemic. Their response is especially relevant for developing countries, given the global footprint and extensive operations (e.g., natural resource mines, factories, assembly plants, warehouses, retail outlets) that going digital MNEs have in these countries, as documented in multiple World Investment Reports (e.g., UNCTAD, 2017, 2020b). The large MNEs have offices and employees in many developing countries and serve customers with physical or digital delivery of products and services in vastly different ways.

Moreover, these MNEs rely on suppliers and other intermediary actors that may also have similarly widely distributed operations, many in developing countries. In this interdependent and interconnected universe, one player deciding to automate its operations forces the other players to, at a minimum, automate their interface with partners (Bienhaus \& Abubaker, 2017). Intermediary actors can also have a significant impact on the MNE's global footprint and CSR activities (Serdijn, Kolk \& Fransen, 2020).

Born digital MNEs are already heavily involved in remote sales in developing countries, operating vast commercial enterprises that are reliant on 4IR technologies to reach millions of customers, often without any physical manufacturing or distribution presence. $^{2}$ As such, their scope to further digitize is limited and their ability to improve the environmental and social conditions of their global employee base and their supply chain partners is likely also limited.

On the other hand, going digitals possess a unique advantage in that they straddle both analog and digital worlds. They still represent the real (physical) economy but they can manufacture and sell physical products and offer the same products as digital services. These hybrid models are increasingly employed by the ICT sector since enterprise hardware can be sold as hardware-as-a-service (HaaS), both as a physical product and a flexible consumption service model. The print media industry has operated consumer-oriented hybrid models for decades (i.e., hard copy newspapers and online subscriptions). 
The flexibility of being able to offer either a brickand-mortar or digital business is critically important for having a commercial presence in developing countries that lack reliable ICT infrastructure or have other technology or skilled labor constraints. Over time, as the reach of the Internet grows larger and online payment processing and transaction security becomes an established feature of the ecommerce platform in developing countries, the going digital MNEs have the flexibility to shift to more digitally intensive production processes. We therefore believe that the pure brick-and-mortar companies that exist today will likely be replaced by hybrid business models that incorporate both digital and analog aspects in their global value chains. In short, going digital MNEs represent the largest population of companies on the brink of substantial digitalization in 4IR; thus, they offer the next springboard for the transformation of GVCs and developing countries.

The triple bottom line that Elkington (1994) set out for MNEs two decades ago - profit, people, and the planet - has only acquired a new urgency. What changes must take place within the MNE and what can policymakers do to ensure that both economic and social imperatives are equally addressed?

\section{ADDRESSING THE ECONOMIC IMPERATIVE}

\section{Distinguishing Between GVCs and GSCs}

Clarifying the differences between global value chains (GVCs) and global supply chains (GSCs) is important to understanding, from the MNE perspective, the types of 4IR technologies in which the going digital MNEs will invest and the possible social impacts of these technologies. ${ }^{3}$

The GVC is a chain of sequential and progressive interconnected activities by which the MNE conducts all of its operations, from corporate strategy and management to product/service conception and design, manufacturing, marketing, sales and distribution, and aftermarket services. ${ }^{4}$ The GVC provides a comprehensive view of the MNE's activities and how they are linked to both commercial and social responsibilities towards customers, investors, vendors, supply chain partners, employees, community stakeholders, and the planetary environment.

The GSC, on the other hand, consists of all the activities in the "order to fulfilment" cycle within one or more of the functional segments of the GVC. There are separate GSCs for sales, manufacturing, R\&D, and so on. Each GSC has employees that manage procurement, logistics, shipment, etc., for that department. ${ }^{5}$ In general, the operational functions of MNEs have GSCs and are the elemental building blocks of GVCs.

Consider, for example, how the sales ("customer order to fulfillment") GSC fits within the MNE's overall GVC. The supply chain begins with the customer placing an order for the MNE's goods or services and ends with the order being fulfilled. In between are activities such as order processing, manufacturing, inventory management, sourcing and procurement, merging, packaging, shipping, warehousing, distribution logistics and delivery. The GSC includes physical flows of goods and services, financial records and fund flows, and legal title flows between related or unrelated parties (Figure 1).

Within the GVC there are functional segments such as strategic planning and capital allocation that have no corresponding GSCs. Furthermore, changes in GVCs or GSCs can affect each other. GVC transformations such as a major corporate acquisition can necessitate the integration and digitalization transformation of several legacy GSCs; and, vice versa, digitalizing a GSC activity such as embedding AI sensors to detect warehouse inventory spoilage can lead to a change in the global procurement segment of the GVC (Merli, 2020). For large going-digital MNEs facing a postpandemic race for survival, it is at the level of GSCs, especially those that have employees and financial investments that span many developing countries, where the question of "socially responsible digitalization" should be raised.

\section{Thriving in 4IR as an Economic Imperative}

Digitalization as an economic imperative has been foremost in the minds of CEOs of brick-and-mortar MNEs for some time. An IBM (2010) survey of 664 CEOs of MNEs in 29 countries identified increasing complexity, volatility, and lack of transparency as the primary limitation to operations growth and financial success. The lean GVCs built by MNEs in the 1990s and 2000s created intricate and highly inter-dependent supply chains with vast numbers of vendors and service providers, each of whom also operated their own complex GSCs without full collaboration and integration across all partners (World Economic Forum, 2019). Data on key operating metrics for order-to-delivery product supply chain and conception-to-obsolescence for R\&D and manufacturing supply chains simply did 


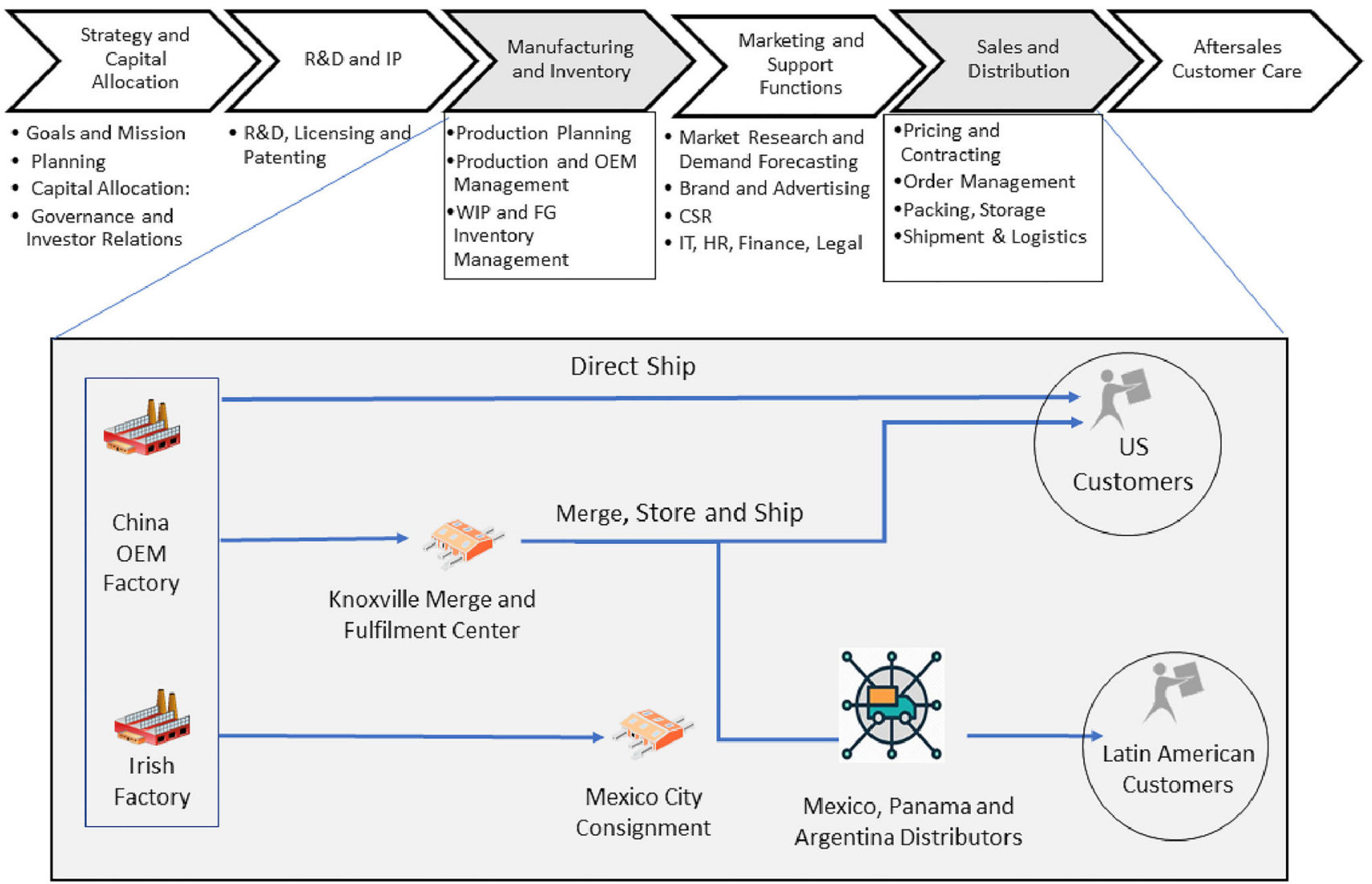

Figure 1 Global value chain and global supply chain with illustrative activities.

not exist. Without critical data, none of the supply chain partners could make quick proactive decisions at critical supply nodes, which ultimately multiplied delays, disruption, and losses for all chain partners. In sum, lean GVCs had interdependent GSCs that lacked transparency and were vulnerable to shocks.

As an example of the positive impacts of 4IR, consider the logistics firm DHL, a bellwether in supply chain transformation and probably the best example of how harnessing all the tools of 4IR can multiply growth and efficiency along the GVC. Beginning in 2015, DHL adopted IOT technology across its supply chain, attaching remote sensors attached to air, land, and marine shipments that generated and transmitted data to be processed by computer algorithms that sent corrective actions and instructions back to the sensors. After the first proof of concept was demonstrated, DHL began to engage some of its large business partners that were struggling with significant point-to-point transportation delays often taking place across multiple time zones and countries where $24 / 7$ person-to- person communication and decision-making were simply not feasible. ${ }^{6}$ IOT provided an automated solution and every partner in the DHL supply chain benefited from predictability, stability, and ultimately, lower cost. ${ }^{7}$

The World Economic Forum (2020a) provides a second example. WEF is now tracking 44 "lighthouse" sites that are early movers on adaptation to 4IR. These going digitals are engaged in connecting their GVCs end-to-end and employing 4IR technologies in their plants. The MNEs include wellknown firms such as Bayer, BMW, GSK, Haier, Hitachi, Johnson \& Johnson, Proctor \& Gamble, Renault, Saudi Aramco, and Tata Steel. The individual case studies conducted by WEF exhibit remarkable improvements in productivity, efficiency, and cost savings, and significant upskilling in workers' roles (see Betti, de Boer \& Giraud, 2020). Their overall assessment is that lighthouses can become the "scale-up vehicle" for the entire MNE group. Notably, a similar role was played by lead plants inside MNEs during the shift from mass to lean production (Eden, 1991). 


\section{Surviving the Pandemic as an Economic Imperative}

In responding to the COVID-19 pandemic, the foremost priority of CEOs has been the safeguarding of the health of their employees, securing all the necessary environmental safety standards in factories, and developing global remote work technologies (World Economic Forum, 2020b). To a large extent, MNEs have accomplished this objective and are now turning to the next two priorities that the COVID-19 crisis has spotlighted: (again) the critical need for greater transparency in GSCs and lessening their dependence on singular critical suppliers. Eighty percent of senior executives surveyed by the World Economic Forum (2020b) see the demand- and supply-side impacts of COVID-19 as moderate to high. Over one-third wanted to leverage new technologies such as IoT and AI to better prepare for supply chain disruption in the future. The general view is that only "ruthless efficiency" can enable them to climb out of severe customer account attrition and widespread factory closures.

Of course, digitalization is not the only way an MNE can recover from the economic stagnation caused by the pandemic. Moreover, organizational resistance to change and fear of uncertainty are powerful barriers to going digital, as demonstrated in Horváth and Szabó (2019). Still, going digitals are now well aware that 'smart' GSCs with predictive digital collaboration across all supply-chain partners are critical for managing the risks associated with supply disruptions. ${ }^{8}$ Risk management in GSCs also involves more than mitigating external shocks; it requires MNE executives to take a systemwide view that manages risks within each GSC link and their interfaces to other GSCs (Lessard, 2013).

Recent research on shocks and responses (Eden, 2019), VUCA (volatility, uncertainty, complexity, and ambiguity) (Buckley, 2020; Eden and Nielsen, 2020; van Tulder, Verbeke, \& Jankowska, 2019b) and COVID-19 (Contractor, 2021; Gereffi, 2020; Verbeke, 2020) also highlight the increasing importance of complexity and uncertainty in the global economy and the need for even greater resiliency in GSCs. ${ }^{9}$ Gereffi's (2020) study, for example, of international trade in personal protective equipment before and during the COVID-19 pandemic documents both policy and market failures, and the need for more resilient supply chains and diversified sourcing. It is important to note that while the pandemic has heightened the need for GVC resilience, discussion about VUCA and GVC reconfiguration has long preceded the crisis (Miroudot, 2020; van Tulder, Verbeke \& Jankowska, 2019b).

\section{ADDRESSING THE JANUS FACE OF DIGITALIZATION}

\section{The Social Costs of Going Digital}

Change always offers both opportunities and threats. Twenty years ago, Eden and Lenway (2001) argued that MNEs were the "Janus face" of globalization. The two-sided (positive and negative) views of the MNE were generated by their three roles in the global economy as market-making firms, investment bridges between countries, and agents of change within countries. The Janus face perspective can provide valuable lessons for how and what actions at the MNE level can produce negative societal impacts that the MNE may not be aware of or legally required to address.

Today, we again see the same concerns being raised by born digitals, the new agents of change, as they bring about a new kind of firm-level internationalization that has been called "digital globalization" (McKinsey Global Institute, 2016). Digital globalization has both "bright" and "dark" sides (benefits and costs), which can cause major shifts in MNE governance, resources, and customer value (Verbeke \& Hutzschenreuter, 2020). For example, there has been much discussion of 4IR causing a "world of scarce work", with negative impacts on workers and on the distribution of income in both developed and developing countries (Vickers \& Ziebarth, 2019: 26).

Recent empirical studies also point to social costs that can result from growing market concentrations, mark-ups, and profits in sectors that intensively use digital technology. Hsieh and RossiHansberg (2019), for example, argue that going digital has enabled service sectors to standardize and scale up their service delivery, resulting in rising industry concentration in the U.S. service, wholesale, and retail sectors. Calligaris, Criscuolo, and Marcolin (2018) provide evidence of rising firm mark-ups across 26 countries over 2001-2014 that were higher in digitally intensive sectors and widened over time relative to other sectors. ${ }^{10}$

Both 4IR and COVID-19 have prompted the going digitals to accelerate and transform the digitalization of their GSCs into 'smart' data-defined networks. A concern is that the adoption of automation, $\mathrm{AI}$, and robotics across MNE GVC and 
supply chains may exacerbate unemployment in developing countries that supply low-skill labor or have vulnerabilities in their supply chains. Since 4IR technologies are inherently complex with increasingly shorter useful lives of intangible assets, going digital MNEs may choose to centralize their $\mathrm{R} \& \mathrm{D}$ in developed countries (e.g., Israel, US), leading to a widening gap in technological skills and institutional voids between developed and lessdeveloped economies. Another adverse impact of GSC digitalization can be the MNE's decision to withdraw its logistics and manufacturing control and personnel from countries with unstable and underdeveloped infrastructure, again leading to unemployment and lowering FDI.

In addition, changes are being made not only within GSCs but also across GVCs. Going digital MNEs headquartered in developed economies are automating costly labor-intensive and repetitive processes and are building "business intelligence" tools to make smarter decisions for demand planning and customer acquisition, the economic benefits of which are earned in developed countries. Digitalization may make it easier for firms to work with suppliers at arm's length but this can make it more difficult to promote social justice and environmental stewardship throughout the value chain (Narula, 2019). Digitization may also lead to increased specialization that raises income inequality both within and between countries (Lorenzen, Mudambi \& Schotter, 2020; Van Assche, 2020).

In sum, the going digitals are early movers whose actions are likely to be mimicked by the fast follower and latecomer firms coming behind them on the 4IR digitalization path. As lead companies among brick-and-mortar businesses, the going digitals can either become agents of stagnation and barriers to change or adopt more socially proactive strategies as they digitalize their GSCs and GVCs.

\section{The Social Benefits of Going Digital}

There is some ground for optimism since the social contract that MNEs have had with their stakeholders is changing due to a growing and deepening awareness of the MNE's interdependency with its myriad and diverse stakeholders, as outlined in Schlegelmilch and Szőcs (2020), Eden (2020), and Van Tulder, Rodrigues, Mirza, and Sexsmith (2021). CEOs of MNEs are slowly committing to the language and importance of SDGs in their global strategies, building value propositions (mission and vision statements) that link their core activities to societal benefits. MNEs that seek to expand their markets or digitalize their supply chains within developing countries are also starting to accept the additional social responsibility that comes with such investments. Moreover, going digital MNEs can also use hybrid business models, offering a brick-and-mortar business in the least-developed economies together with a digitalized business model in economies where 4IR is more advanced.

Digitalization initiatives around GSCs can create social benefits for MNE stakeholders (e.g., suppliers, employees, customers, and communities). As the DHL example shows, there are many scalable and cost-effective digital solutions that can potentially multiply one MNE's efficiency improvements in its GSC and benefit partners all along the chain. The World Economic Forum (2015), for example, identifies 31 supply-chain practices in consumer-facing businesses that can trigger a "triple advantage": (i) increasing profitability of the MNE (revenue, cost, risk, and brand value); (ii) contributing to local development and societies (customer health, local labor wages, and working conditions); and (iii) making a positive environmental impact (carbon emissions).

Similarly, McKinsey Global Institute (2018) studied 160 cases where AI was used to address social issues. Many of the cases did not require "moon shot" scientific breakthroughs but, rather, contributed to existing R\&D efforts to help individuals or groups in both advanced and developing economies that live beyond the reach of traditional or commercial solutions. McKinsey identified ten domains across all 17 SDGs where adding AI to the solution mix could have large-scale social impact (the four largest domains were health and hunger, education, security and justice, and equality and inclusion).

We provide some examples where digitalization of GSCs can have positive social impacts. For example, the mining industry has arguably one of the most complex and often hazardous supply chains, with labor-intensive processes for underground detection, ore extraction, and transportation in and out of the mines. Several large mining MNEs have launched "intelligent mines" where autonomous trucks, trains, and drills are networked and connected to all components of the mining value chain. Using a digital replica of the processing plant that is accessible in real time by workers outside the mine, the data analytics capabilities and simulations help optimize production in manner that protects human health and safety. In 
addition, the redundant mine workers are retrained for new jobs on site. ${ }^{11}$

Grocery retail supply chains are another example where digitalizing inventory systems can lead the MNE to identify where and how food waste (unpurchased or no longer edible) occurs and can be reduced and redistributed. The World Resource Institute and its partners ${ }^{12}$ estimate that a staggering 33\% of all food is lost or wasted between the farm and plate, resulting in approximately $8 \%$ of annual greenhouse gas emissions. In 2019, Champions 12.3 , a voluntary coalition of executives from business, government and civil society, created the "10 $1020 \times 30$ " initiative ${ }^{13}$ in which ten large food retailers each engage 20 of their priority suppliers to work towards achieving SDG Target 12.3, which calls for a $50 \%$ reduction in worldwide food loss and waste by $2030.10 \times 20 \times 30$ takes a wholesupply-chain approach, with retailers working to reduce in-store food loss and waste while supporting farms and suppliers on similar efforts.

End-to-end supply-chain changes also require visibility into the sources of food waste generation and smart real-time decisions to convert it to animal feed, compost, or energy. Walmart, the world's largest retailer, runs a program called Project Gigaton that encourages its suppliers to standardize date labeling, measure, and report food waste, and introduce practices for reprocessing, donating, and recycling. The company invests billions in IOT and blockchain technology. Sensors and machine vision cameras can improve loading accuracy and estimated times of arrival while blockchain improves the traceability of produce and aid recalls. ${ }^{14}$

Mirroring food waste is electronic waste or ewaste, e.g., electronic consumer products and enterprise hardware embodying outdated technology and now sit in or are bound for landfills (Baldé et al., 2017). Old laptops, TVs, monitors, and personal devices are largely made up of plastic or materials hazardous to humans and nature. By investing in advanced material science, PC manufacturers such as Dell Technologies can retrieve and recycle the plastic waste deposited in the oceans to make molded trays for equipment packaging. In addition to reducing the use of virgin plastics, these firms have found new ways to recycle carbon fibers to remanufacture laptops. ${ }^{15}$ Thus, the adoption of 4IR technologies such as advanced materials and blockchain may help brick-and-mortal MNEs internalize the negative externalities that they generate.

\section{NAVIGATING THE ECONOMIC AND SOCIAL IMPERATIVES}

\section{Three Proposals for Navigating the Imperatives}

The twin pressures of thriving in 4IR and recovering from the economic setback of the pandemic are lending a new momentum to the transformation of the GSCs and GVCs of going digitals. In this transformation, there is a window of opportunity where MNEs can successfully navigate both the economic and social imperatives over the next decade. Behavioral and policy changes are needed by the going digital MNEs that encompass: (i) revamping the CSR function at the GSC level; (ii) making SDGs matter at the GVC level through other behavioral/governance changes by and within the MNE; and (iii) the creation of a broad coalition between MNEs and multilateral organizations, which in tandem can bridge the gap between economic and social imperatives. We elaborate on each category below and provide both general recommendations and specific actions.

\section{Revamping the CSR Function for 4IR}

MNEs are chartered by their shareholders to grow profitably, pay their employees, and provide a financial return to their investors. This fiduciary duty includes product safety, quality standards, and worker and consumer health and welfare. The "business of business is profit" as Friedman (1970) and Levitt (1958) argued, is the narrowest definition of the fiduciary responsibility of the MNE's leaders. The MNE's motivation to go above and beyond these fiduciary duties requires not only enlightened leaders but also a robust CSR function that can continually identify, advocate, and organize the MNE's supply-chain operations to orient investments towards socially responsible goals and programs.

According to McKinsey Global Institute (2018), 90\% of MNEs have some form of a CSR program. Despite CSR being a well-established vehicle that MNEs have used to navigate their social commitments for decades, the CSR department in most MNEs remains sidelined from the urgent and major investments in 4IR and digitalization and is focused more narrowly on the MNE's environmental and social programs. The CSR function's primary role is unchanged: to prepare an annual Sustainability Report and marketing collateral to append to a customer bid package or government tender. 
We argue that in the next decade, it is the CSR department within going digital MNEs that can and must do more to ensure that investment in GSC digitalization is convergent with SDG progress. This in turn, requires that the CSR function reports to or works closely with the departments that are key decision makers and operational drivers of 4IR investments, viz., supply chain strategy, manufacturing strategy and operations, R\&D, IT, commercial finance, and capital allocation teams. The CSR department must acquire controlling and governance rights within the MNE and act as both an advisor and a gatekeeper, allowing the MNE to invest in only those digitalization strategies that fully remediate unemployment or other socially adverse impacts that it creates in developing-country GSC partners.

One way to accomplish this shift in the CSR role within the MNE is to create an "SDG SWAT" team that brings together CSR, Finance, Supply Chain, Manufacturing, and Human Resources. In planning for IOT, AI, and automation along the supply chain, the SWAT team's role would be to provide detailed and economically viable alternatives that incorporate SDG-related actions and investments. ${ }^{16}$ The SWAT team would also be tasked to develop the value proposition (mission, vision, etc.) for different business lines, enabling the conceptual linking of the SDGs to the core activities of the MNE, including its GSCs. Moreover, the SWAT team must be empowered by the MNE's executive leadership to veto any 4IR plans that do not create a net-positive social impact.

In addition to the creation of an SDG SWAT team, going digital MNEs must also address the difficult problem of assessing the relative values of different social investments. A longstanding limitation to evaluating net social impact has been the lack of economic models to quantify the value of SDG-related investments. MNEs struggle with confusing and often misleading return on SDG investment indicators. ${ }^{17}$ In contrast, the financial return on GSC digitalization investments that are on the minds of MNE leaders today are easier to quantify and have a shorter payback period. It is easy for firms to fall back on qualitative reporting of SDG progress, but reporting does not per se provide the motivation for MNEs to invest in an "optimal" level in SDGs. If the returns from SDG-related investments cannot be quantified, they cannot be compared to the MNE's allocation of capital to 4IR and in turn, the MNE will underinvest in SDG activities. Evidence-based decision-making requires that decision makers have good evidence (Eden \& Wagstaff, 2020; Lynberg, Rogers \& Wood, 2010).

MNE finance departments do not have the capacity to decipher the difficult problem of measuring the return on their SDG investment. The tools and models that economists employ to estimate the value of positive externalities and social net benefit for public policy analysis and decisions have not reached MNEs, whether digital or going digital. Moreover, these models must be adapted to use MNE financial data. Economists and academics, with the assistance of trade associations and multilateral agencies, must take the initiative to research and develop models that MNEs can effectively utilize.

Making SDGs Matter for MNEs at the GVC Level While the increased transparency and reporting of SDG impacts by MNEs across their value chains are important, the reality is that CSR is still considered a "ticket to play". In general, MNEs spend much of their talent, capital, and time on delivering value for shareholders. Without an unrelenting SDG mindset, there is lower bandwidth for creative social thinking inside the firm. For MNEs to become robust protagonists for SDGs, certain aspects of their investment goals, measurement of returns, and enabling organizations must change. We list a few of the behavioral and organizational changes that, if adopted, would go a long way towards removing roadblocks to increased SDG investments.

\section{SDG pledge}

The CEOs of the world's largest MNEs could be encouraged to sign an "SDG Pledge" that has incentivizing outcomes like that of the Giving Pledge for philanthropy. The pledge could be modeled on the seven Women's Empowerment Principles that UN Women has invited CEOs of MNEs to sign and implement in their organizations, which are designed to "mainstream" gender equality (UN Women, 2019).

\section{Expanding the share of wallet}

A declaration by the CEO, backed up by significant financial commitment, is a powerful tool to introduce SDG investments in the MNE's capital allocation decisions. CSR must be assigned a larger share of wallet (i.e., percent of the MNE's budget allocated to a particular activity or function). With an expanded wallet, CSR moves up from a side lineitem into the MNE's principal financial goals, 
alongside digitalization, acquisitions, new product introductions, dividends, compensation and bonuses, and all other investments that fulfil its economic imperative. ${ }^{18}$ The CSR function then becomes embedded in core processes across the GVC such as quarterly and annual financial planning and commercial expansion and marketing decisions.

\section{Mandatory mapping of CSR to SDGs}

MNEs can internally mandate that each CSR program must be linked to SDGs and related activities, as well as to SASB and the Global Impact Investing Network metrics. Standardized SDG reporting can be made a requirement for Audit Committee reviews especially when the MNE has commenced a multi-year digitalization of its GSC for greater visibility along the supply chain. There are various ways to encourage going digitals to map their CSR programs to the SDGs. Eden and Wagstaff (2020) develop an SDG Materiality Matrix and show how the matrix can be used to help an MNE select and implement the SDG goals and targets that are most appropriate for its circumstances. The authors illustrate the selection and implementation process with a case study of SDG5 Gender Equality and argue that the matrix can be applied across a wide variety of MNEs and SDGs. Nachum (2019: 439440) provides a simple SDG identification and mapping tool using a $2 \times 2$ input-output matrix based on private and social benefits. As long as the output of an MNE's societal services can be internalized within the MNE (i.e., the firm can earn a measurable private benefit), the MNE will be incentivized to invest in such services, in particular, when it possesses within its own network the core assets to do so. PricewaterhouseCoopers (2016) provides a guide on how an MNE can operationalize SDG-related activities within its CSR program. ${ }^{19}$ UNCTAD $(2018,2019)$ also provide useful insights on mapping CSR to the SDGs.

\section{Separate SDGs, giving, and diversity and inclusion (D\&I)}

MNEs often include their headquarter D\&I activities and philanthropy within their CSR goals. Greater D\&I in the headquarters of US and European MNEs has a proven positive impact on revenue generation and philanthropy has a powerful and immediate effect in combating critical environmental and human emergencies. Since the private and social benefits from D\&I and philanthropy are more visible and quantifiable than SDG- related activities, the latter may be given lower funding priority especially where the overall budget for all three activities is small and fixed. By reorganizing the three activities under different departments in the GVC and defining separate processes for evaluating performance and measuring returns, more attention can be paid to tracking pure SDG-related activities. This also ensures that in times of business downturn when capital is scarce, the MNE continues to prioritize its SDG activities as a necessary investment.

\section{A New MNE-UN Coalition}

Our third recommendation is the creation of a new public-private partnership linking going digital MNEs to the United Nations, which would create opportunities to link the economic and social imperatives through dialogue and joint action. We agree with Eden and Wagstaff (2020), Van Tulder et al. (2019a), van Zanten and van Tulder (2018), and Zhan (2021) that applying 4IR technology to the challenges of achieving SDGs requires public-private partnerships and multilateral collaboration, within a framework of shared values and collective impact as laid out by Kramer and Pfitzer (2016).

We therefore recommend forming a new coalition that connects UNCTAD, either alone or together with another UN agency or WEF, to the CEOs, CFOs, and CSR officers of the largest going digital MNEs. We recommend that UNCTAD be the lead partner in this effort for several reasons. UNCTAD is the entity within the UN system that is responsible for international trade, investment, and development issues and has universal and credible representation for investment-development stakeholders worldwide. Its value proposition is "prosperity for all" and its goals are "maximize the trade, investment, and development opportunities of developing countries and assist them in their efforts to integrate into the world economy on an equitable basis" (https://unctad.org/about). The agency has five decades of research capability and collects and generates the data to publish comprehensive analyses on MNEs and FDI. Moreover, the agency has well-established capacity building programs that link the SDGs to FDI in developing countries. $^{20}$

The MNE and UN partners, which would voluntarily enroll in this coalition, would jointly determine a mapping of MNEs to some minimum number of SDGs. The partners would help prioritize MNE CSR budgets towards SDGs and activities that 
best align to their economic imperative. We suggest that this coalition have a governance structure, operating cadences, and deliverables that are modeled along the lines of the successful and longstanding Business at OECD coalition (BIAC; http:// biac.org). The multilateral agency or agencies would be responsible for researching and identifying unique SDG investment opportunities and the MNEs for programming, execution, and delivering on the SDG targets to which both parties have agreed. Several times a year, the CSR officers of the MNEs would meet with officers of UNCTAD, review new specific opportunities, and co-develop a game-plan for actions and outcome measurement. The coalition would engage advisors, specialists, and scientists to prepare feasibility studies and define metrics and value measurement, which would be paid for by the MNEs and governments in developing countries that stand to gain the largest benefit.

The coalition would also assess what public policies in developing countries are needed to provide MNEs with the critical minimum telecommunications infrastructure for investing in 4IR technologies. This is still a major hurdle in the path of digitalization (Katz, 2020). As one example, consider the mining industry. Intelligent mining requires a stable Internet connection in remote locations that are deep underground, and security of sensitive information about oil reserves is a prerequisite for investable projects. A robust intellectual property rights (IPR) regime and easing digital infrastructure capacity gaps and bottlenecks can be an integral part of the solutions that the coalition designs.

Through this new coalition, a partnership among national statistical agencies, private sector coalition members, and NGOs could be forged and chartered with the mission to identify and solve data gaps and determine how to prevent a breach of personal data privacy for commercial interest. The coalition must challenge bureaucratic inertia to define IPR and standards for data protection and build institutions that can responsibly accredit NGOs and non-profits as well as CSR groups within MNEs to utilize the data towards 4IR solutions. The data generation and governance activity could be modeled on the successful, pioneering role that UN Women has played in building a comprehensive database of gender statistics (Eden \& Wagstaff, 2020). ${ }^{21}$

\section{CONCLUSION}

Zhan (2021) raises several important trade and investment policy questions to drive the research agenda and actionable items around changes in GVCs. He discusses how GVCs will grow shorter and more regionalized due to increased protectionism coupled with greater domestic regulation and intervention in tax, trade, and digital commerce. Advanced digital technology, especially automation, AI and IOT, will make MNE global value chains shorter, more dynamic, and capable of reaching more customers and vendors faster.

Our paper has focused on GVCs and GSCs as viewed by the MNE and how the investments in digitalization can be aligned to SDG goals. We agree with Zhan's arguments and use them as a springboard for thinking about how traditional brick-andmortar MNEs must digitalize their supply chains and value chains to create resilience in the postpandemic decade ahead. COVID-19 clearly highlighted that the MNEs that were unable to anticipate risk or make quick proactive changes experienced greater revenue decline.

Addressing only the economic imperative of building commercial resilience in a digitalized VUCA world, however, ignores the window of opportunity that digitalization also presents for the going digital MNEs to take the social impacts of their investments into account when making these changes. Going digitals can build responsible GSCs and GVCs that create positive net social benefits. Our paper has outlined three changes that must be made to ensure that the MNEs' economic imperative also facilitates progress on the SDGs: (i) revamping the CSR function, (ii) making the SDGs "matter", and (iii) building a new UN-MNE coalition. Thus, we believe it is possible to use this window of opportunity to also move forward on the UN's social imperative of achieving its pledge to leave no one behind.

Our paper makes several contributions to the international business and public policy literature. First, our paper confirms and builds on the arguments in Zhan (2021) on how 4IR will change MNE value chains and the likely implications for developing countries. Second, we build on the call for IB scholars to incorporate the GVC approach into their research, focus on grand challenges, and address public policy issues (Gereffi, 2019). We also contribute to the literatures on Industry 4.0 and the COVID-19 pandemic by exploring their impacts on the GVCs and GSCs of going digital MNEs. In 
addition, we further the literature on CSR and the SDGs by exploring how the CSR function in MNEs could be better adapted to the SDGs. Lastly, we contribute to recent work on shocks and responses, crises, and a VUCA world.

Our paper highlights several areas for future discussion and potentially productive research and commercial application. One unresolved issue is that of measuring social benefit for MNE investment, on digitalization or otherwise. The finance department in an MNE needs a reasonably accurate tool that leverages its standard financial reporting; public policy economists that assess the social benefit/cost of public goods could step into this arena and create hedonic pricing models or opportunity cost estimations for industry. Secondly, while we have focused on GSC digitalization as the primary post-pandemic CEO priority, we acknowledge that there are other short-run actions that may have positive economic returns and SDG impact, which could be evaluated but lie outside the scope of this paper. Thirdly, we acknowledge that the going digitals population encompasses a large number of MNEs by size, industry, and business models; the parsing of these firms into subgroups may yield a differentiated set of recommendations for their governance and contributions. Lastly, the role that the born digital MNEs, especially global mega e-commerce platforms such as Amazon and Alibaba (Wu \& Gereffi, 2019), play in downstream digitalization of their partners in developing countries should be examined and a separate set of policy recommendations developed for these MNEs.

We believe that the most successful going digitals, in terms of recovery, growth and profitability over the next decade, will be those firms that address the dual challenges of global competitiveness and social citizenship. A window of opportunity to tackle both social and economic imperatives can be opened if going digital MNEs and UN agencies work together to harness and direct 4IR investment for social progress.

\section{NOTES}

${ }^{1}$ See, for example, Bolwijn, Casella and Zhan (2019), Casella and Formenti (2018), Eden (2016, 2019), Elms and Low (2013), McKinsey Global Institute (2013), Mettler and Williams (2011), OECD (2014, 2017a, b), Strategy Dynamics Global SA (2013), and van Tulder, Verbeke, and Piscitello (2019a).
${ }^{2}$ Some e-commerce platform MNEs such as Amazon began as born digitals but have vertically and horizontally integrated into brick-and-mortar distribution. These hybrid models have a unique set of post-pandemic challenges and are an important area for future research. See Wu and Gereffi (2019).

${ }^{3}$ We also acknowledge the long history of research on MNEs and global production networks (e.g., Coe \& Yeung, 2015, 2019; Fuller \& Phelps, 2018; Kano, 2018; Yeung \& Coe, 2015), as a separate classification from GVCs and GSCs.

${ }^{4}$ Although the value chain is typically shown as linear, building on Porter (1980), in practice value chains can have a variety of shapes (UNCTAD, 2013), and can also be conceptualized as value shops and value networks (Stabell \& Fjeldstad, 1998). Moreover, value chains can be conceptualized at the industry or the firm level. Our paper focuses on the GVC from the MNE perspective because we are interested in a particular category of MNEs (going digitals) and their likely responses to 4IR and the pandemic.

${ }^{5}$ At a macro level, as Gereffi (2020) points out, the geographic distribution of GSCs can vary by industry and over time with value creation unevenly distributed across the chain.

${ }^{6}$ https://www.dhl.com/global-en/home/press/ press-archive/2017/dhl-and-huawei-accelerateinbound-to-manufacturing-logistics.html.

${ }^{7}$ Pharmaceutical companies have been on the forefront of end-to-end digitalization of their GVCs, and finding the balance between greater data transparency and protection for all intermediaries (e.g., doctors, regulatory agencies, patients, insurance companies). IOT is a critical part of that search for greater systemic efficiency. We thank Philippe Paumier for this point.

${ }^{8}$ It is useful to note that the links between digitalization and resilience of GSCs depends also on their configuration and design principles (e.g., global-local, B2B, B2C, end-to-end, or only partial supply chains).

${ }^{9}$ Interestingly, Gouda and Saranga (2018) find a positive relationship between a MNE's sustainability effort and lower supply chain risk measured in terms of disruptions and delays.

${ }^{10}$ Van Assche (2020) also discusses the growing importance of intangibles in GVCs and the implications for public policy.

${ }^{11} \mathrm{An}$ example of harnessing 4IR technologies in extractive industries is the Rio Tinto Mine of the Future $^{\mathrm{TM}}$ program implemented in Koodaideri, Australia, where the MNE is investing in upskilling 
labor and training for new roles required by the autonomous technology. Hecla Mining Co., Glencore and Newtrax have also shifted to automating mine ventilation, electricity consumption and truck loading and hauling using AI tools. See https://www.miningglobal.com/supply-chain-andoperations/rio-tinto-mine-future and https:// australianminingreview.com.au/features/

koodaideri-project-breaking-ground/.

${ }^{12}$ WRI webinar, November 24, 2020. https:// www.wri.org/events/2020/11/webinar-global-callaction-food-loss-and-waste.

${ }^{13}$ The $10 \times 20 \times 30$ 's founding partners are AEON, Ahold Delhaize, Carrefour, IKEA Food, Kroger, METRO AG, Pick n Pay, The Savola Group, Sodexo, Tesco, and Walmart. Five of the ten MNEs are the largest food retailers in the world and operate in more than 80 countries.

${ }^{14}$ https://supplychainanalysis.igd.com/ comment-and-opinion/article/t/learning-from-thebest-walmarts-approach-to-supply-chain-tech/i/ 22457 and Walmart (2020).

${ }^{15}$ https://www.delltechnologies.com/en-us/ corporate/social-impact/advancing-sustainability/ sustainable-products-and-services/materials-use/ waste-as-a-resource.htm

${ }^{16}$ The terms CSR, SDG, CSR, Environmental and Social Governance (ESG), Economic, Environmental and Social Governance (EESG), and Impact Investing are often used interchangeably (for distinctions see UNCTAD, 2014). In this paper, the terms "SDG-related activities" and "SDG-related expenditure" refer to the broad range of an MNE's investments in improving environmental, societal, and human conditions that are present along their GVCs.

${ }^{17}$ Measurement tools range from brief qualitative surveys of customers to, in rare cases, financial return on investment metrics (McKinsey, 2009). A few of the larger MNEs have licensed software from the Sustainability Accounting Standards Board ("SASB"); see https://www.sasb.org/licensing-use/ firms/ and SASB (2020). UNCTAD (2019) provides useful guidance on SDG indicators for governments and MNEs.

${ }^{18}$ While each MNE in practice decides how much CSR is "large enough", it is interesting to note that the 2013 India Company Act, issued by the Ministry of Corporate Affairs, mandates that $2 \%$ of the revenue of an MNE's Indian subsidiary (or an Indian company) be applied to certain defined CSR investments.

${ }^{19}$ https://www.pwc.com/gx/en/sustainability/ publications/PwC-sdg-guide.pdf.

${ }^{20}$ See, for example, Zhan (2019), https://unctad. org/project/facilitating-investment-sdg-sectorsdeveloping-countries, and Division on Investment and Enterprise - Products and Services (unctad.org).

${ }^{21}$ It is important to note that MNEs should not be solely responsible for closing the gap in SDG financing nor held accountable for problems that arise from an erosion of institutional capacity or sovereign governance in a country that hosts the MNE's commercial operations. However, a direct interlock between MNE leaders (and their CSR officers) with multilateral trade and investment organizations such as UNCTAD, can play a vital role in changing business mindset and increasing investments in SDGs.

\section{ACKNOWLEDGEMENTS}

The authors gratefully acknowledge helpful comments on earlier drafts of this paper from JIBP Editor-in-Chief Sarianna Lundan, two anonymous reviewers, Richard Bolwijn, Peter Buckley, Gary Gereffi, Lilac Nachum, Philippe Paumier, Karl Sauvant, Bodo Schlegelmilch, Matthew Stephenson, Oliver Treidler, Fernanda Wagstaff, and James Zhan. We retain responsibility for any remaining errors or omissions. The views expressed herein are the authors and do not represent the views of NERA, Texas A\&M or any other organizations with which we or they are affiliated either at present or in the past.

\section{REFERENCES}

Baldé, C. P., Forti, V., Gray, V., Kuehr, R., \& Stegmann, P. 2017. The Global E-waste Monitor 2017. United Nations University (UNU), International Telecommunication Union (ITU) \& International Solid Waste Association (ISWA), Bonn/Geneva/ Vienna.

Banalieva, E.R., \& Dhanaraj, C. 2019. Internalization theory for the digital economy. Journal of International Business Studies, 50: 1372-1387.
Betti, F., de Boer, E., \& Giraud, Y. 2020. Industry's fast-mover advantage: Enterprise value from digital factories. Operation Practice. January. McKinsey \& Co.

Bienhaus, F., \& Abubaker, H. 2017. Procurement 4.0: Factors influencing the digitisation of procurement and supply chains. Business Process Management Journal, 24: 4.

Bolwijn, R., Casella, B, \& Zhan, J. 2019. International production and the digital economy. In Verbeke, A., van Tulder, R., \& 
Piscitello, L. (eds.) International business in the information and digital age. Progress in international business research, 13: 3964. Bingley: Emerald Publishing Ltd and European International Business Academy.

Buckley, P. J. 2020. The theory and empirics of the structural reshaping of globalization. Journal of International Business Studies, 51: 1580-1592.

Calligaris, S., Criscuolo, C., \& Marcolin, L. 2018. Mark-ups in the digital era. OECD Science, Technology and Industry Working Papers, 2018/10. Paris: OECD.

Casella, B., \& Formenti, L. 2018. FDI in the digital economy: A shift to asset-light international footprints. Transnational Corporations, 25(1): 101-130.

Cattaneo, O., Gereffi, G., \& Staritz, C. (Eds.) 2010. Global value chains in a postcrisis world: A developmental perspective. Washington, DC: The World Bank.

Chowdhury, A., \& Sundaram, J. K. 2021. Developing countries struggling to cope with COVID-19. International Development Economics Associates. February 24. https://www. networkideas.org/news-analysis/2021/02/developingcountries-struggling-to-cope-with-covid-19/.

Coe, N. M., \& Yeung, H. W. 2015. Global production networks: Theorizing economic development in an interconnected world. Oxford: Oxford University Press.

Coe, N. M., \& Yeung, H. W. 2019. Global production networks: Mapping recent conceptual developments. Journal of Economic Geography, 19: 775-801.

Contractor, F. 2021. The world economy will need even more globalization in the post-pandemic 2021 decade. Journal of International Business Studies, forthcoming.

East, D., \& Kaspar, M. G. 2020. The impact of COVID-19 on manufacturing investments. Industry Analytics Platform. August. Vienna, Austria: UNIDO. https://iap.unido.org/ articles/impact-covid-19-manufacturing-investments.

Eden, L. 1991. Multinational responses to trade and technology changes: Implications for Canada. In D. McFetridge (Ed.), Foreign Investment, technology and economic growth. The Investment Canada Research Series Volume 1: 133-171. Calgary: University of Calgary Press.

Eden, L. 2016. Multinationals and Foreign Investment Policies in a Digital World. The e15 Task Force on Investment Policy, World Economic Forum and the International Centre for Trade and Sustainable Development. February. http://e15initiative.org/ publications/multinationals-and-foreign-investment-policiesin-a-digital-world/

Eden, L. 2018. The Fourth Industrial Revolution: Seven lessons from the past. Working Paper. July 18. https://papers.ssrn.com/ sol3/papers.cfm?abstract_id=3244096.

Eden, L. 2019. The Fourth Industrial Revolution: Seven Lessons from the Past. In A. Verbeke, R. van Tulder, \& L. Piscitello, (Eds.), International business in the information and digital age. Progress in international business research, 13: 39-64. Bingley: Emerald Publishing Ltd and European International Business Academy.

Eden, L. 2020. The social responsibility of multinationals - From an after-thought to center stage. In B. Schlegelmilch, \& I. Ilona Szöcs (Eds.), Rethinking business responsibility in a global context - Challenges to corporate social responsibility, sustainability and ethics: 1-18. Springer Series: CSR, Sustainability, Ethics \& Governance.

Eden, L., \& Molot, M. A. 1996. Made in America? The Auto Industry in the 1990s. The International Executive 384(July/ August): 501-541.

Eden, L., \& Nielsen, B. B. 2020. Research methods in international business: The challenge of complexity. Journal of International Business Studies, 51: 1609-1620.

Eden, L., \& Lenway, S. 2001. Introduction to the symposium Multinationals: The Janus Face of globalization. Journal of International Business Studies, 32(3): 383-400.
Eden, L., \& Wagstaff, M. F. 2020. Evidence-based policymaking and the wicked problem of SDG 5 gender equality. Journal of International Business Policy. https://bit.ly/3eZNACD.

Elkington, J. 1994. Towards the sustainable corporation: Winwin-win business strategies for sustainable development. California Management Review, 36(2): 90-100.

Elms, D. K., \& Low, P. (Eds.) 2013. Global value chains in a changing world. Fung Global Institute (FGI), Nanyang Technological University (NTU), and World Trade Organization (WTO). Geneva, CH: World Trade Organization.

Enderwick, P., \& Buckley, P. 2020. Rising regionalization: Will the post-COVID-19 world see a retreat from globalization? Transnational Corporations, 27(2): 99-112.

Friedman, M. 1970. The social responsibility of business is to increase its profits. The New York Times Magazine. September 13, p. 379. https://nyti.ms/1LSi5ZD.

Fuller, C., \& Phelps, N. A. 2018. Revising the multinational enterprise in global production networks. Journal of Economic Geography, 18: 139-161.

Gereffi, G. 2019. Global value chains and international development policy: Bringing firms, networks and policy-engaged scholarship back in. Journal of International Business Policy 2(3): 195-210.

Gereffi, G. 2020. What does the COVID-19 pandemic teach us about global value chains? The case of medical supplies. Journal of International Business Policy, 3: 287-301.

Gouda, S.K., \& Saranga, H. 2018. Sustainable supply chains for supply chain sustainability: Impact of sustainability efforts on supply chain risk. International Journal of Production Research, 56(17): 5820-5835.

Hsieh, C. T., \& Rossi-Hansberg, E. 2019. The industrial revolution in services (No. w25968). National Bureau of Economic Research. June. http://www.nber.org/papers/w25968.

Horváth, D., \& Szabó, R. Z. 2019. Driving forces and barriers of Industry 4.0: Do multinationals and small and medium-sized companies have equal opportunities? Technological Forecasting \& Social Change, 146: 119-132.

IBM. 2010. New rules for a new decade. A vision for smarter supply chain management. Global Business Services Executive Report, IBM Global Value Institute.

Kano, L. 2018. Global value chain governance: A relational perspective. Journal of International Business Studies, 49: 684705.

Katz, R. 2020. Economic impact of COVID-19 on digital infrastructure: Report of an Economic Experts Roundtable organized by ITU. GSR-20 Discussion Paper. July.

Kobrin, S. J. 2017. Bricks and mortar in a borderless world: Globalization, the backlash, and the multinational enterprise. Global Strategy Journal, 7(2): 159-171.

Kramer, M., \& Pfitzer, M. 2016. The ecosystem of shared values. Harvard Business Review (October): 80-89.

Lessard, D. 2013. Uncertainty and risk in global supply chains. In D. K. Elms, \& P. Low (Eds.), 2013. Global Value Chains in a Changing World: 195-219. Fung Global Institute (FGI), Nanyang Technological University (NTU), and World Trade Organization (WTO). Geneva, CH: World Trade Organization.

Levitt, T. 1958. The dangers of social responsibility. Harvard Business Review, 36(5): 41-50.

Lorenzen, M., Mudambi, R., \& Schotter, A. 2020. International connectedness and local disconnectedness: MNE strategy, city-regions and disruption. Journal of International Business Studies, 51(8): 1199-1222.

Lynberg, S., Rogers, J., \& Wood, D. 2010. From transparency to performance: Industry-based sustainability reporting on key issues. The Hauser Center for Non-Profit Organizations at Harvard University. Published for The Initiative for Responsible Investment, Harvard University Press.

Merli, G. 2020. Digitalizing the supply chain to enable new value chains. EFESC Consulting (www.efeso.com). http://bit. ly/38nVnZI 
Mettler, A., \& Williams, A. D. 2011. The rise of the micromultinational: How freelancers and technology-savvy start-ups are driving growth, jobs and innovation. Lisbon Council Policy Brief Vol. V, No. 3.

McKinsey \& Co. 2009. Valuing social responsibility programs. July. McKinsey Quarterly. https://www.mckinsey.com/ quarterly/overview.

McKinsey Global Institute. 2013. Disruptive technologies: Advances that will transform life, business, and the global economy. May. McKinsey \& Company.

McKinsey Global Institute. 2016. Digital globalization: The new era of global flows. March. McKinsey \& Company.

McKinsey Global Institute. 2018. Notes from the Al Frontier, Applying Al for Social Good. December. McKinsey \& Company.

McKinsey Global Institute. 2020a. How COVID-19 has pushed companies over the technology tipping point - and transformed business forever. October. McKinsey \& Company.

McKinsey Global Institute. 2020b. The next normal: The recovery will be digital, digitalizing at speed and scale. August. McKinsey \& Company.

Miroudot, S. 2020. Reshaping the policy debate on the implications of COVID-19 for global supply chains. Journal of International Business Policy, 3(4): 430-442.

Monaghan, S., Tippmann, E, \& Coviello, N. 2020. Born digitals: Thoughts on their internationalization and a research agenda. Journal of International Business Studies, 51: 11-22.

Nachum, L. 2019. How much social responsibility should MNEs strategically assume and of which kind? In L. C. Leonidou, C. S. Katsikeas, S. Samiee, \& C. N. Leonidou, (Eds.), Socially responsible international business: Critical issues and the way forward: 433-461. Cheltenham: Edward Elgar.

Narula, R. 2019. Enforcing higher labor standards within developing country value chains: Consequences for MNEs and informal actors in a dual economy. Journal of International Business Studies, 50(9): 1622-1635.

Nature. 2020. Get the sustainable development goals back on track. Nature, 577(January 2): 7-8. https://doi.org/10.1038/ d41586-019-03907-4.

OECD. 2014. Addressing the tax challenges of the digital economy. Paris: OECD Publishing.

OECD. 2017a. The future of global value chains: Business as usual or "a new normal?" OECD Science, Technology and Innovation Policy Papers, No. 41 (July). Paris: OECD Publishing.

OECD. 2017b. The next revolution: Implications for governments and business. Paris: OECD Publishing.

$\varnothing$ verby, H., \& Audestad, J. A., 2018. Digital economics: How information and communication technology is shaping markets, businesses, and innovation. CreateSpace Independent Publishing Platform.

Porter, M. 1980. Competitive strategy: Techniques for analyzing industries and competitors. Free Press: New York.

PricewaterhouseCoopers. 2016. Navigating the SDGs: a business guide to engaging with the UN Global Goals. https://www.pwc. com/gx/en/sustainability/publications/PwC-sdg-guide.pdf.

Roos, D., Jones, D. T., \& Womack, J. P. 1990. The machine that changed the world: The story of lean production. New York, NY: Simon \& Schuster Inc.

Schlegelmilch, B., \& Ilona Szőcs, I. (Eds.), 2020. Rethinking business responsibility in a global context - Challenges to corporate social responsibility, sustainability and ethics. Springer Series: CSR, Sustainability, Ethics \& Governance. New York: Springer International Publishing.

Schwab, K. 2016. The fourth industrial revolution. Geneva, $\mathrm{CH}$ : World Economic Forum.

Serdijn, M., Kolk, A., \& Fransen, L. 2020. Uncovering missing links in global value chain research - And implications for corporate social responsibility and international business. Critical Perspectives on International Business. https://doi.org/ 10.1108/cpoib-01-2020-0002
Stabell, C. B., \& Fjeldstad, O. D. 1998. Configuring value for competitive advantage: On chains, shops, and networks. Strategic Management Journal, 19: 413-437.

Strategy Dynamics. 2013. The Emerging Digital Economy. Global Trends Briefing, June. Strategy Dynamics Global SA. www. globaltrends.com.

Sustainability Accounting and Standards Board (SASB). 2020. WwW.sasb.org.

UNCTAD. 2013. World investment report 2013: Global value chains - Investment and trade for development. Geneva: United Nations.

UNCTAD. 2014. World investment report 2014: Investing in the SDGs: An action plan. Geneva: United Nations.

UNCTAD. 2017. World investment report 2017: Investment and the digital economy. Geneva, $\mathrm{CH}$ : United Nations.

UNCTAD. 2018. Harnessing frontier technologies for sustainable development. Technology and Innovation Report 2018. Geneva, CH: United Nations.

UNCTAD. 2019. Guidance on core indicators for entity reporting on contribution towards implementation of the sustainable development goals. Geneva, $\mathrm{CH}$ : United Nations

UNCTAD. 2020a. Transforming trade and development in a fractured post-pandemic world. Report of the Secretary-General of the UNCTAD to the Fifteenth Session of the Congress. Geneva, $\mathrm{CH}$ : United Nations.

UNCTAD. 2020b. World investment report 2020: International production beyond the pandemic. Geneva, $\mathrm{CH}$ : United Nations.

United Nations. 2016. Transforming our world: The 2030 Agenda for Sustainable Development. Resolution adopted by the General Assembly on 25 September 2015. A/RES/70/1. UN General Assembly, Seventieth Session. Agenda items 15 and 116. New York: United Nations.

UN Women. 2019. WE EMPOWER: Responsible business conduct in $G 7$ countries. New York, United Nations.

Van Assche, A. 2020. Trade, investment and intangibles: The ABCs of global value chain-oriented policies. OECD Trade Policy Papers No. 242. Paris: OECD Publishing.

Van Tulder, R., Rodrigues, S. B., Mirza, H., \& Sexsmith, K. 2021. The UN's sustainable development goals: Can multinational enterprises lead the Decade of Action? Journal of International Business Policy, 4: 1-21.

Van Tulder, R., Verbeke, A., \& Piscitello, L. (Eds.), 2019. International business in the information and digital age. Progress in International Business Research, vol. 13. Bingley: Emerald Publishing Ltd and European International Business Academy.

Van Tulder, R., Verbeke, A., \& lankowska, B. (Eds.), 2019. International business in a VUCA World: The changing role of states and firms. Progress in international business research, vol. 14. Emerald Publishing Ltd and European International Business Academy, pp. 39-64.

Van Zanten, J. A., \& van Tulder, R. 2018. Multinational enterprises and the Sustainable Development Goals: An institutional approach to corporate engagement. Journal of International Business Policy, 1: 208-233.

Van Zanten, J. A., \& van Tulder, R. 2020. Beyond COVID-19: Applying "SDG logics" for resilient transformations. Journal of International Business Policy, 3: 451-464.

Verbeke, A. 2020. Will the COVID-19 pandemic really change the governance of global value chains? British lournal of Management, 31: 444-446.

Verbeke, A., \& Hutzschenreuter, T. 2020. The dark side of digital globalization. Academy of Management Perspectives. https:// doi.org/10.5465/amp.2020.0015.

Vickers, C. \& Ziebarth, N. L. 2019. Lessons for today from past periods of rapid technological change. UN/DESA Working Paper No. 158. ST/ESA/2019/DWP/158.

Walmart. 2020. Environmental, social \& governance report. https://corporate.walmart.com/esgreport/ 
World Economic Forum. 2015. Beyond supply chains. Empowering responsible value chains. White Paper prepared in collaboration with Accenture, January.

World Economic Forum. 2019. Supply chain collaboration through advanced manufacturing technologies, White Paper, October.

World Economic Forum. 2020a. Global lighthouse network: Insights from the forefront of the fourth industrial revolution. White Papers. January 10. Geneva.

World Economic Forum. 2020b. How to rebound stronger from COVID-19 Resilience in manufacturing and supply systems, White Paper, April.

Wu, X., \& Gereffi, G. 2019. Amazon and Alibaba: Internet governance, business models, and internationalization strategies. In A. Verbeke, R. van Tulder, \& L. Piscitello, (Eds.), International business in the information and digital age. Progress in international business research, 13: 327-356. Bingley: Emerald Publishing Ltd and European International Business Academy.

Yeung, H. W., \& Coe, N. M. 2015. Toward a dynamic theory of global production networks. Economic Geography, 91(1): 2958.

Zhan, J. X. 2019. WIF@10: Achievements and Challenges ahead. The World Investment Forum Review. https:// worldinvestmentforum.unctad.org/wp-content/uploads/ 2020/01/WIF@10_Review_achievements_James_Zhan_12. 2019.pdf.

Zhan, J. X. 2021. GVC Transformation and a new investment landscape in the 2020s: Driving forces, directions, and a forward-looking research and policy agenda. Journal of International Business Policy.
Zhan, J. X., \& Santos-Paulino, A. U. 2021. Investing in the sustainable development goals: mobilization, channeling and impact. Journal of International Business Policy, 4: 166-183.

\section{ABOUT THE AUTHORS}

Niraja Srinivasan is a partner in the global transfer pricing practice at NERA Economic Consulting and is based in Washington, DC. Her research and consulting interests are transfer pricing controversy management for multinationals. Prior to NERA, she held tax leadership roles in Fortune 50 companies. She has a PhD in applied economics from the Wharton School, University of Pennsylvania.

Lorraine Eden is Professor Emerita of Management and Research Professor of Law at Texas A\&M University. Her current research interests are transfer pricing and MNE strategies in the digital economy. She has been editor-in-chief of JIBS, president of the Academy of International Business, and is currently dean of the AIB Fellows. She has a PhD in economics from Dalhousie University.

Publisher's Note Springer Nature remains neutral with regard to jurisdictional claims in published maps and institutional affiliations.

Accepted by Sarianna Lundan, Editor-in-Chief, 17 March 2021. This article has been with the authors for two revisions and was single-blind reviewed. 